\title{
KEMAMPUAN TANAMAN GLODOGAN Polyalthia longifolia SoNN. SEBAGAI PENEDUH JALAN DALAM MENGAKUMULASI Pb UDARA BERDASARKAN RESPON ANATOMIS DAUN DI PURWOKERTO
}

\author{
RizQi DWi Ardyanto, Slamet SAntoso, Siti SAMIYARSiH
}

Fakultas Biologi, Universitas Jenderal Soedirman, Jalan dr. Suparno 63 Purwokerto 53122

\section{A B S T R A C T}

Polyalthia longifolia is a plant that used as a roadside in Purwokerto. This study aimed to determine the ability of the plant $P$. longifolia in the air and accumulate $\mathrm{Pb}$ anatomic response to the $\mathrm{Pb}$ concentration in the leaves of $P$. longifolia. The methods of research used survey methods. Roadside plant leaf samples were taken by purposived sampling at six locationsmain street in Purwokerto, there are Jenderal Soedirman, Dr. Soeparno, HR. Bunyamin, Commisioner Bambang Soeprapto and Gerilya. The independent variable was the ambient air Pb and $\mathrm{Pb}$ leaf was the dependent variable. The main parameters investigated were air $\mathrm{Pb}$ concentrations, $\mathrm{Pb}$ leaves, stomata anatomical characters and thick mesophyll tissue. Parameter support was the traffic density. The results showed that the highest concentration of $\mathrm{Pb}$ in the air with a concentration of $0.1020 \mu \mathrm{g} / \mathrm{m}^{3}$ per hour on Gerilya street and the lowest in DR. Soeparno street with concentrations of $0.0048 \mu \mathrm{g} / \mathrm{m}^{3}$ per hour, it can be concluded that an ambient air $\mathrm{Pb}$ in six study sites are still under ambient air quality in Central Java, which is $2 \mu \mathrm{g} / \mathrm{m}^{3}$ per 24 hours. Leaf Pb concentration was highest in HR. Bunyamin street with a concentration of $0.4980 \pm 0.004 \mathrm{ppm}$ and lows in the DR. Soeparno street with concentrations of $0.2786 \pm 0.008 \mathrm{ppm}$. Pb accumulated in leaves affects the density, length, and width of stomata and mesophyll tissue thickness $P$. longifolia. Pb concentrations was not correlate with the leaf $\mathrm{Pb}$ concentration $P$. longifolia. $\mathrm{Pb}$ concentrations of leaves of $P$. longifolia is closely linked with decreasing density of stomata and mesophyll tissue thickness but not related to the length and width of the stomata.

KEY WORDS: ambient air $\mathrm{Pb}, \mathrm{Pb}$ leaves of $P$. longifolia, anatomical characters

Penulis korespondensi: RIzQI DWI ARDYANTO | email: riez.dwiardy@yahoo.co.id

\section{PEN DAH ULUAN}

Purwokerto sebagai ibukota Kabupaten Banyumas merupakan pusat berbagai macam kegiatan yang membutuhkan sarana transportasi sebagai penunjang kegiatan, sehingga menyebabkan pesatnya pertambahan kendaraan terutama kendaraan pribadi. Kendaraan bermotor menjadi salah satu sumber utama pencemaran udara, karena mengandung berbagai bahan pencemar yang berbahaya. Menurut Fergusson (1990) bahan pencemar (polutan) yang berasal dari gas kendaraan bermotor umumnya berupa gas hasil sisa pembakaran dan partikel logam berat yaitu $\mathrm{Pb}$.

$\mathrm{Pb}$ merupakan suatu logam berat yang lunak berwarna kelabu kebiruan dengan titik leleh $327 \stackrel{\circ}{\circ} \mathrm{C}$ dan titik didih $1.620^{\circ} \mathrm{C}$, pada suhu $550-600{ }^{\circ} \mathrm{C}$ dapat menguap dan bereaksi dengan oksigen di udara membentuk timbal oksida (PbO) dan senyawa organometalik. Logam $\mathrm{Pb}$ digunakan untuk meningkatkan bilangan oktan pada bahan bakar kendaraan bermotor biasanya untuk mengurangi letupan selama proses pembakaran di dalam mesin. Cairan anti letupan yang lazim dipakai adalah timbal tetraetil $\left(\mathrm{Pb}\left(\mathrm{C}_{2} \mathrm{H}_{5}\right)_{4}\right)$ dan timbal tetrametil $\left(\mathrm{Pb}\left(\mathrm{CH}_{3}\right)_{4}\right)$ atau campurannya. Senyawa tersebut pada proses pembakaran akan melepaskan partikel-partikel $\mathrm{Pb}$ dalam bentuk $\mathrm{PbCl}, \mathrm{PbBr}_{2}, \mathrm{PbBrCl}, \mathrm{PbO}$, dan $\mathrm{PbO}_{4}$ tidak larut dalam air dan sisanya dilepaskan ke udara (Wardhana, 2001). Pb pada konsentrasi yang tinggi (100-1000 ppm) dapat mengakibatkan pengaruh toksik terhadap proses fotosintesis sehingga pertumbuhan akan terhambat (Widowati et al. 2008). Di Indonesia, Premium atau bensin mengandung $\mathrm{Pb}$ sebesar 0,84 g/L yang melebihi kandungan maximum dari Negara-negara lain misalnya Amerika Serikat sebesar 0,13 g/L, Jerman Barat 0,15 g/L, Jepang 0,31 g/L (Hendrasarie, 2007).

Menurut Antari dan Sundra (2007), Polyalthia longifolia merupakan jenis tanaman yang memiliki akar yang dapat bertahan terhadap kerusakan yang disebabkan oleh getaran kendaraan, mudah tumbuh di daerah panas dan tahan terhadap angin sehingga cocok digunakan sebagai tanaman peneduh jalan yang akan dapat menyerap unsur pencemaran yang berasal dari asap kendaraan bermotor khususnya $\mathrm{Pb}$. $P$. longifolia merupakan jenis pohon yang tingginya 10$25 \mathrm{~m}$, batangnya lurus, daunnya tunggal berseling, berbentuk elips memanjang dan tebal, warna daun hijau tua, panjangnya $12,5-20 \mathrm{~cm}$, lebar 2,5-5 cm. Bunga axial, berwarna kuning kehijau-hijauan, dan tajuknya berbentuk kerucut. Klasifikasi dalam taksonomi P. longifolia adalah divisi Spermatophyta, sub divisi Angiospermae, kelas Dicotiledonae, ordo Magnoliales, familia Annonaceae, marga Polyalthia, jenis P. longifolia (Sulasmini dalam Ruhaibah, 2011).

Tanaman peneduh jalan $P$. longifolia dapat di jumpai di Jalan dr Angka hingga Dr Suharso, Jalan Gerilya, Jalan H. R Bunyamin, Jalan DR. Soeparno, Jalan Komisaris Bambang Soeprapto, dan Jalan Jenderal Soedirman dengan tingkat kepadatan lalu lintas yang berbeda. Diharapkan melalui pengkajian di enam lokasi tersebut dapat diketahui kemampuan tanaman $P$. longifolia dalam mengakumulasi $\mathrm{Pb}$ udara.

Menurut Iwan dalam Santoso (2011), karakter yang umum pada tanaman yang mempunyai kemampuan untuk menyerap polutan indoor maupun outdoor yang cukup tinggi yaitu tanaman memiliki 
tajuk rimbun, tidak gugur daun, dan tinggi. Terakumulasinya sebagian besar logam berat yang berlebihan, menyebabkan penurunan kualitas, baik pertumbuhan maupun produktivitas tanaman atau bahkan berdampak kematian jika sudah melewati ambang batas toleransi (Hughes et al, 1980). Menurut Malhotra dan Khan dalam Treshow, et al. (1989), kerusakan tanaman karena pencemaran udara berawal dari tingkat biokimia (gangguan proses fotosintesis, respirasi, serta biosintesis protein dan lemak), selanjutnya tingkat ultrastruktural (disorganisasi sel membran), kemudian tingkat sel (dinding sel, mesofil, pecahnya inti sel) dan diakhiri dengan terlihatnya gejala pada jaringan daun seperti klorosis dan nekrosis.

\section{MET ODE}

Materi yang digunakan dalam penelitian adalah daun Polyalthia longifolia yang diambil dari 6 jalan di Kota Purwokerto, yaitu di jalan dr. Angka hingga Dr. Suharso, Jalan Gerilya, Jalan H. R Bunyamin, Jalan Dr. Soeparno, Jalan Komisaris Bambang Soeprapto, dan Jalan Jenderal Soedirman. Kemikalia yang digunakan antara lain $\mathrm{Pb}\left(\mathrm{NO}_{3}\right)_{2}$, $\mathrm{HNO}_{3} 1 \%, \mathrm{H}_{2} \mathrm{O}_{2} 20 \%, \mathrm{HNO}_{3}$ pekat, $\mathrm{HCl}$ pekat, akuades, alkohol 96\%, alkohol absolut, xilol, gliserin, dan parafin.

Alat-alat yang digunakan adalah mikroskop, hand counter, mikrometer okuler, object glass, mikrometer objektif, mikrometer square, timbangan analitik, oven, pipet ukur, pipet tetes, kuvet, cawan furnace, filter membrane, Middle Air Volume Sampler (MVAS), Total Suspended Particulate (TSP), Spektrofotometer Serapan Atom (SSA), muffle furnace, labu destruksi, gelas ukur, gelas piala 1000 $\mathrm{mL}$, corong, botol film, kertas Whatman no. 42, wrapping, gunting, silet, kertas label, kamera digital, kantong plastik dan alat tulis.

Partikel udara ditangkap di enam lokasi penelitian dengan menggunakan Middle Volume Air Sampler (MVAS) selama 1 jam. Alat menggunakan filter berbentuk lingkaran (bulat) dengan porositas 0,3-0,45 $\mu \mathrm{m}$. Kecepatan pompa yang dipakai untuk penangkapan suspensi Particulate Matter adalah 50 - 500 Lpm. Metode ini digunakan untuk mendapatkan TSP (Total Suspended Partikulate) yang kemudian diambil filtrat timbalnya dan diuji dengan alat Spektrofotometer Serapan Atom (SSA).

Pengambilan sampel daun $P$. longifolia dilakukan dengan menggunakan bantuan alat seperti gunting, galah atau bambu dan benang kasur. Galah atau bambu diikat menggunakan benang kasur untuk mengambil daun. Pengambilan sampel daun dilakukan secara random sampling pada beberapa tanaman $P$. longifolia yang terdapat di lokasi pengambilan sampel. Pengambilan daun dilakukan pada cabang pohon yang mengarah ke jalan dan daun tua dengan umur yang relative sama, tidak terhalang oleh benda lain dari arah jalan. Ketinggian daun antara 1-3 m di atas permukaan tanah. Daun yang diambil merupakan daun yang sehat yang dicirikan oleh warna hijau, tidak ada kerusakan yang diakibatkan oleh hama atau penyakit. Sampel daun dimasukkan ke dalam plastik secara terpisah berdasarkan lokasi pengambilan sampel, namun terlebih dahulu dibersihkan dengan menggunakan akuades.

Kepadatan lalu lintas dinyatakan dalam satuan kendaraan bermotor per jam, dihitung dengan menggunakan hand counter dalam jangka waktu selama satu jam. Pengukuran kepadatan lalu lintas dilakukan tiga kali yaitu pagi (pukul 08.00 - 09.00 WIB), siang (pukul
13.00 - 14.00 WIB), dan sore (pukul 16.00 - 17.00 WIB). Perhitungan dipisahkan antara mobil dan motor.

Filter membrane yang berasal dari Total Suspended Particulate (TSP) disiapkan. Filter membrane yang terpapar $\mathrm{Pb}$ diukur dan dicatat panjang serta lebar (mm) dihitung luasnya $\left(\mathrm{mm}^{2}\right)$. Filter membrane dipotong menjadi 4 bagian yang sama, kemudian dihitung dan dicatat luasnya $\left(\mathrm{mm}^{2}\right)$. Satu bagian sampel filter membrane tersebut diambil dan dimasukan ke dalam gelas piala $200 \mathrm{~mL} .60 \mathrm{~mL}$ larutan $\mathrm{HCl}$ (1+2) ditambahkan ke dalam gelas piala $200 \mathrm{~mL} .5 \mathrm{ml} \mathrm{H} \mathrm{O}_{2}$ pekat ditambahkan dan mulut gelas piala ditutup dengan kaca arloji. Gelas piala diletakkan di atas pemanas listrik, sampel dipanaskan selama kurang lebih satu jam pada temperatur $105^{\circ} \mathrm{C}$. Gelas piala diturunkan dari pemanas. 5 $\mathrm{mL} \mathrm{H}_{2} \mathrm{O}_{2}$ pekat ditambahkan kembali dan pemanasan dilanjutkan di atas pemanas listrik selama 30 menit. Sampel didinginkan dan selanjutnya dilakukan penyaringan. Kaca arloji dibilas dengan sejumlah air bersamaan dengan penyaringan sampel. Sampel disaring dengan kertas saring dan filtrat ditampung pada gelas piala $200 \mathrm{~mL}$. $50 \mathrm{~mL}$ larutan $\mathrm{HCl}(1+2)$ ditambahkan kembali pada gelas piala pada langkah pertama. Sampel filter membrane dipanaskan selama 30 menit untuk residu terlebih dahulu. Sampel filter membrane didinginkan dan kemudian dilakukan penyaringan kembali. Filtrat pada gelas piala $200 \mathrm{~mL}$ disatukan. Filtrat dipanaskan sampai mendekati kering (sisa cairan tinggal sedikit) atau terbentuk Kristal atau garam. 10 $\mathrm{mL} \mathrm{HNO}_{3}(2+98)$ ditambahkan ke dalam gelas piala, dilanjutkan pemanasan selama beberapa menit (sampai seluruh residu terlarut). Sampel didinginkan dan disaring, filtrat ditampung dalam labu ukur $50 \mathrm{~mL}$. Gelas piala dibilas dengan $\mathrm{HNO}_{3}(2+98)$ kemudian ditepatkan sampai tanda tera. Sampel uji siap dianalisis dengan SSA. langkah awal hingga akhir di ulang untuk pengujian blanko.Nilai serapan kadar timbal dalam contoh uji dihitung dengan rumus :

$$
C_{P b}=\frac{\left(C_{t}-C_{b}\right) \times V_{t} \times \frac{S}{S_{t}}}{V}
$$

Keterangan :

$\mathrm{C}_{\mathrm{Pb}}$ adalah kadar timbal di udara $\left(\mu \mathrm{g} / \mathrm{m}^{3}\right)$

$\mathrm{C}_{\mathrm{t}}$ adalah kadar timbal dalam larutan contoh uji yang di spike $(\mu \mathrm{g} / \mathrm{mL})$

$\mathrm{C}_{\mathrm{b}}$ adalah kadar timbal dalam larutan blanko $(\mu \mathrm{g} / \mathrm{mL})$

$\mathrm{V}_{\mathrm{t}}$ adalah volum larutan contoh $\mathrm{uji}(\mathrm{mL})$

$\mathrm{S}$ adalah luas contoh uji yang terpapar debu pada permukaan filter $\left(\mathrm{mm}^{2}\right)$

$\mathrm{S}_{\mathrm{t}}$ adalah luas contoh uji yang digunakan $\left(\mathrm{mm}^{2}\right)$

$\mathrm{V}$ adalah volume udara yang dihisap dikoreksi pada kondisi normal $25^{\circ} \mathrm{C}, 760 \mathrm{mmHg}\left(\mathrm{m}^{3}\right)$.

Daun yang telah dioven kemudian dipotong kecil-kecil kemudian di timbang, dimasukkan kedalam cawan porselen, lalu dipanaskan dalam muffle furnace pada suhu $700^{\circ} \mathrm{C}$. Masukkan abu tersebut pada beker glass, tuang perlahanlahan $\mathrm{HNO}_{3}$ pekat dan $\mathrm{H}_{2} \mathrm{O}_{2}$. Kemudian di saring menggunakan kertas whatman no.42.

Pengukuran konsentrasi timbal (Pb) dilakukan menggunakan Spektrofotometri Serapan Atom (SSA) Larutan dimasukkan ke dalam nebulizer, dikabutkan dan diuapkan kemudian disinari dengan sinar katoda pada panjang gelombang 283,3 nm dan kuat arus 3,5 mA. Hasil serapan lampu akan ditangkap oleh detector dan besarnya kandungan logam $\mathrm{Pb}$ akan terlihat di layar monitor dan dicetak pada printer.

Pembacaan penentuan $\mathrm{Pb}$ pada daun dilakukan menggunakan rumus $\mathrm{y}=\mathrm{b} \mathrm{x}+\mathrm{a}$ dengan keterangan bahwa $\mathrm{y}$ adalah absorbansi pembacaan SSA dan $\mathrm{x}$ adalah konsentrasi larutan baku $\mathrm{Pb}$ (ppm). Kalibrasi dilakukan untuk 
mengetahui berapa nilai untuk setiap skala pada mikrometer okuler jika dikonversikan ke dalam satuan mikrometer $(\mu \mathrm{m})$.

Sayatan daun diletakkan di object glass, ditetesi dengan air lalu ditutup dengan cover glass dan diamati di bawah mikroskop. Dihitung nilai kalibrasi panjang dan lebar stomata yang tertera pada mikrometer okuler kemudian dikalikan kalibrasi. Kerapatan atau jumlah stomata dihitung dengan menggunakan mikrometer square yang dipasang pada tabung okuler, kemudian dihitung jumlah stomata di dalam bujur sangkar. Untuk mengukur tebal mesofil daun dibuat irisan melintang daun dengan menggunakan metode parafin, pewarnaan dengan safranin 1\% dalam alkohol $76 \%$. Pengirisan daun dengan menggunakan mikrotom dengan tebal irisan $10 \mu \mathrm{m}$. Pengukuran tebal mesofil dilakukan dengan mikrometer okuler, kemudian dikalikan dengan nilai kalibrasi.

Data konsentrasi $\mathrm{Pb}$ udara ambien yang diperoleh dibandingkan dengan baku mutu udara ambien di Propinsi Jawa Tengah berdasarkan SK Gubernur Jawa Tengah Nomor 8 Tahun 2001. Untuk mengetahui kemampuan penyerapan $\mathrm{Pb}$ udara ambien oleh daun $P$. longifolia dan pengaruhnya terhadap respon anatomis, maka dilakukan analisis ragam
(ANOVA), sedangkan untuk mengetahui hubungan $\mathrm{Pb}$ daun dengan respon anatomis daun $P$. longifolia dilakukan analisis regresi linear dengan melihat nilai koefisien korelasi antara konsentrasi $\mathrm{Pb}$ daun dengan karakter anatomis.

\section{HASIL DAN PEMBAHASAN}

Berdasarkan pemantauan terhadap tingkat kepadatan lalu lintas di enam lokasi penelitian, di peroleh hasil tingkat kepadatan tertinggi berada di jalan Jenderal Soedirman dengan jumlah kendaraan yang melintas $3527 \pm 212,89$ kendaraan per jam. Di lokasi lain yaitu di jalan Gerilya, Komisaris Bambang Suprapto, H.R. Bunyamin, dr Angka dan Dr. Soeparno berturut-turut mengalami penurunan yaitu masing-masing 3148,67 \pm 94,235 kendaraan per jam, 3089,33 $\pm 99,91$ kendaraan per jam, 2789 $\pm 168,78$ kendaraan per jam, $2440 \pm 2372$ kendaraan per jam, dan 2223,33 $\pm 184,46$ kendaraan per jam. Berdasarkan hasil pemeriksaan konsentrasi $\mathrm{Pb}$ udara ambien dan $\mathrm{Pb}$ pada daun $P$. longifolia di lokasi penelitian dapat dilihat pada tabel 1 .

Tabel 1. Konsentrasi Pb udara ambien dan $\mathrm{Pb}$ pada daun P. longifolia di enam lokasi penelitian

\begin{tabular}{lcc}
\hline \multicolumn{1}{c}{ Jalan } & $\begin{array}{c}\text { Konsentrasi Pb udara ambien } \\
\left(\mu \mathrm{g} / \mathrm{m}^{3} \text { per jam }\right)\end{array}$ & $\begin{array}{c}\text { Rata-rata konsentrasi Pb pada daun P. Longifolia } \\
(\mathrm{ppm})\end{array}$ \\
\hline Jend. Soedirman & 0,0147 & $0,2756 \pm 0,001$ \\
Gerilya & 0,1020 & $0,3324 \pm 0,022$ \\
HR. Bunyamin & 0,0131 & $0,4980 \pm 0,004$ \\
dr. Angka - Soeharso & 0,0115 & $0,4689 \pm 0,002$ \\
DR. Soeparno & 0,0048 & $0,2786 \pm 0,008$ \\
Kom. Bambang Suprapto & 0,1011 & $0,3063 \pm 0,004$ \\
\hline
\end{tabular}

Berdasarkan SK Gubernur Jawa Tengah Nomor 8 Tahun 2001 tentang Baku Mutu Udara Ambien di Propinsi Jawa Tengah, nilai ambang batas $\mathrm{Pb}$ adalah 2 $\mu \mathrm{g} / \mathrm{m}^{3}$ selama 24 jam, sehingga dapat disimpulkan bahwa konsentrasi $\mathrm{Pb}$ udara ambien di enam jalan utama di Purwokerto masih di bawah ambang batas yang ditetapkan.

Hasil ANOVA menunjukkkan bahwa $\mathrm{Pb}$ udara ambien berpengaruh sangat nyata terhadap $\mathrm{Pb}$ pada daun $P$. longifolia. Kemampuan tanaman $P$. longifolia dalam mengakumulasi $\mathrm{Pb}$ udara dapat dilihat pada Grafik 1. Berdasarkan grafik 1 diinformasikan bahwa, kemampuan tanaman $P$. longifolia dalam mengakumulasi $\mathrm{Pb}$ udara ambien cenderung berbanding lurus dengan peningkatan konsentrasi $\mathrm{Pb}$ di udara namun di beberapa lokasi penelitian mengalami penurunan dalam mengakumulasi $\mathrm{Pb}$ udara ambien walaupun konsentrasi $\mathrm{Pb}$ udara di lokasi tersebut relatif tinggi. Kondisi semacam ini dimungkinkan karena penurunan kemampuan tanaman dalam menyerap $\mathrm{Pb}$ udara ambien. Hasil penelitian sesuai dengan pendapat Widagdo (2005), yang menyatakan bahwa keefektifan tanaman dalam menyerap polutan sampai batas tertentu akan semakin berkurang dengan peningkatan konsentrasi polutan.

Pada suatu batas ketahanan masing-masing jenis, tanaman juga menampakkan gejala kerusakan akibat pencemaran udara. Berdasarkan hasil pengukuran jumlah stomata daun P.longifolia diperoleh informasi bahwa jumlah stomata pada daun $P$. longifolia tertinggi terdapat di jalan Dr. Soeparno yaitu 41,56 \pm 11,381 per $\mathrm{mm}^{2}$ dan jumlah stomata terendah terdapat di jalan dr. Angka - dr. Soeharso yaitu 20,78 $\pm 2,5386$ per $\mathrm{mm}^{2}$. Menurut Haryanti (2010) jumlah stomata per satuan luas $\left(\mathrm{mm}^{2}\right)$ diklasifikasikan dalam 5 katagori yaitu sedikit (1-50 stomata per $\mathrm{mm}^{2}$ ), cukup banyak (51-100 stomata per $\mathrm{mm}^{2}$ ), banyak (101-200 stomata per $\mathrm{mm}^{2}$ ), sangat banyak (201-300 stomata per $\mathrm{mm}^{2}$ ), tak hingga (301-700 stomata per $\mathrm{mm}^{2}$ ). Hasil penelitian menunjukkan jumlah stomata di enam lokasi penelitian dikatagorikan sedikit yaitu berkisar 20,78 - 41,56 stomata per $\mathrm{mm}^{2}$.

Hasil ANOVA dapat disimpulkan bahwa konsentrasi $\mathrm{Pb}$ daun berpengaruh sangat nyata terhadap jumlah stomata. Semakin meningkat konsentrasi $\mathrm{Pb}$ yang terserap dalam daun maka jumlah stomata semakin menurun. Hasil uji korelasi antara $\mathrm{Pb}$ daun dengan jumlah stomata didapatkan nilai $r>0,05$ sehingga dapat disimpulkan bahwa ada hubungan antara konsentrasi $\mathrm{Pb}$ daun $P$. longifolia terhadap jumlah stomata dengan persamaan regresi linier yang didapat yaitu $\mathrm{Y}=53,0211-64,1014 \mathrm{X}$ (Grafik 2)

Berdasarkan hasil analisis regresi linier antara $\mathrm{Pb}$ daun $P$. longifolia dengan jumlah stomata didapatkan nilai $t>0,01$ sehingga dapat disimpulkan bahwa ada hubungan sangat nyata antara konsentrasi $\mathrm{Pb}$ yang terakumulasi dalam daun dengan jumlah stomata, semakin meningkat konsentrasi $\mathrm{Pb}$ yang terserap 
dalam daun maka jumlah stomata semakin menurun, namun derajat keeratan hubungan $\left(r^{2}\right)$ antara $P$. longifolia dengan jumlah stomata hanya sebesar $30 \%$.

Berdasarkan hasil pengukuran panjang stomata daun P.longifolia diperoleh informasi bahwa panjang stomata pada daun $P$. longifolia tertinggi terdapat di jalan Jend. Soedirman yaitu 26,40 $\pm 6,12 \mu \mathrm{m}$ dan panjang stomata terendah terdapat di jalan DR. Soeparno yaitu $18,13 \pm 2,12 \mu \mathrm{m}$. Di lokasi lain yaitu di jalan dr Angka- dr. Soeharso, Gerilya, HR. Bunyamin, dan Kom. Bambang Suprapto panjang stomata daun P. longifolia berturut-turut mengalami peningkatan yaitu masing-masing $22,67 \pm 3,82 \mu \mathrm{m} ; 23,47 \pm 3,35 \mu \mathrm{m}$; $24,53 \pm 1,60 \mu \mathrm{m}$ dan $24,80 \pm 3,60 \mu \mathrm{m}$.

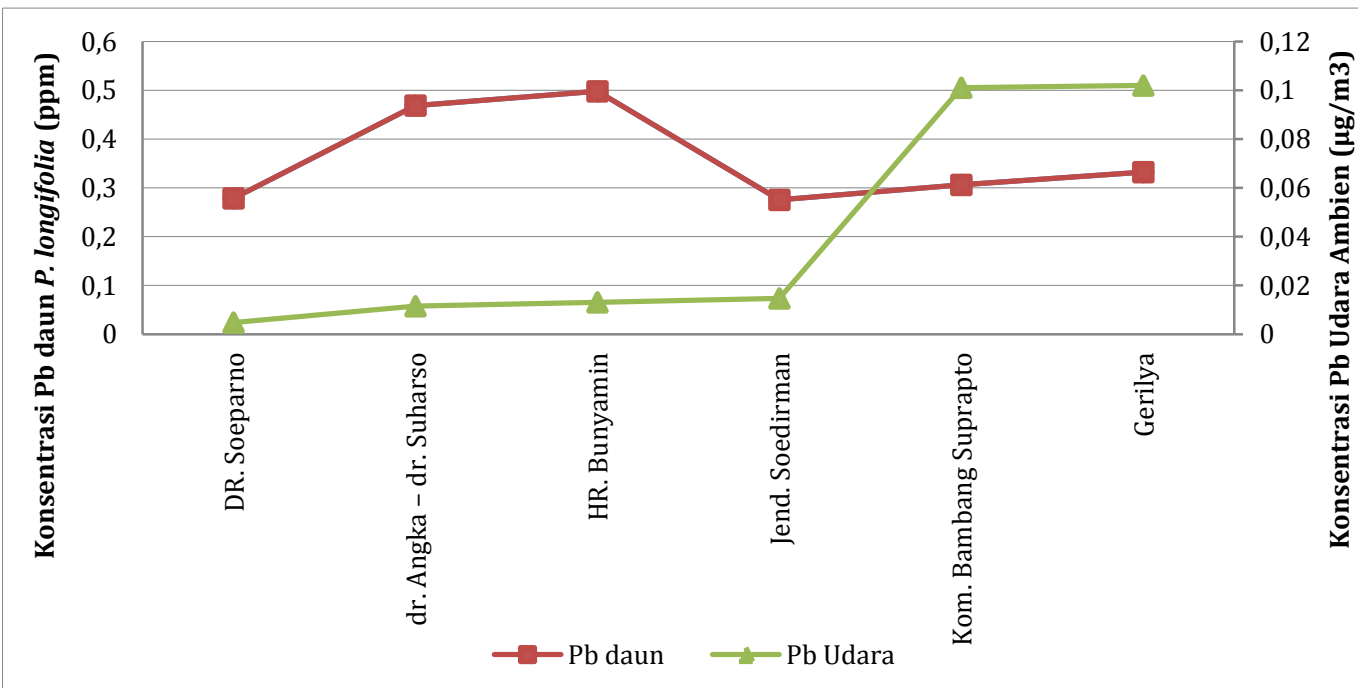

Grafik 1. Kemampuan tanaman P. longifolia dalam mengakumulasi $\mathrm{Pb}$ udara

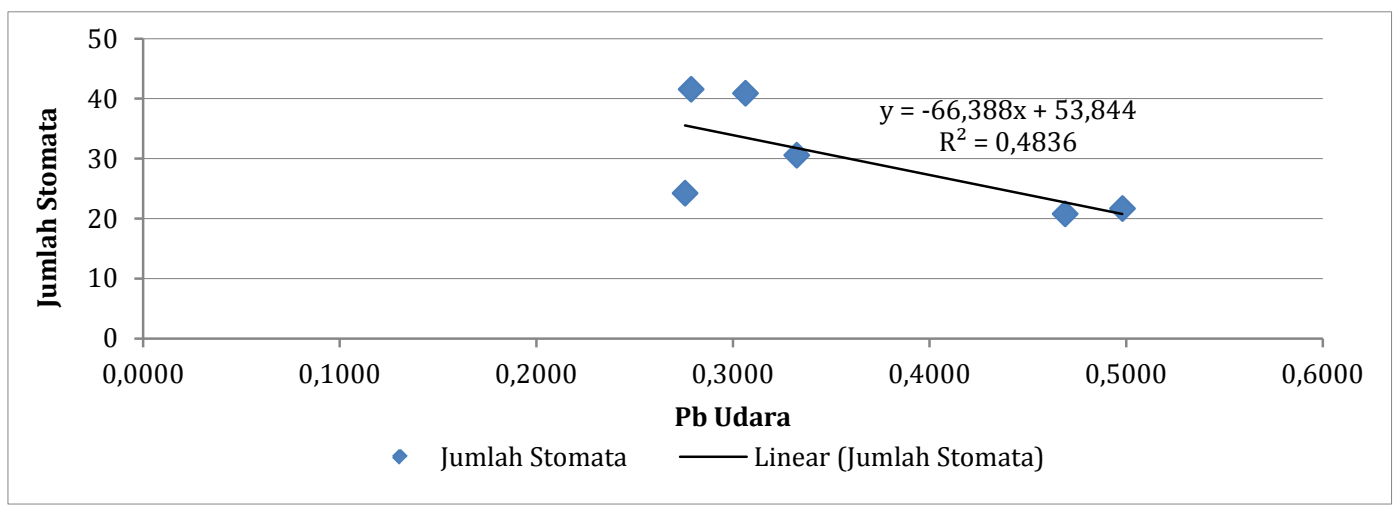

Grafik 2. Korelasi $\mathrm{Pb}$ daun P. longifolia dengan kerapatan stomata

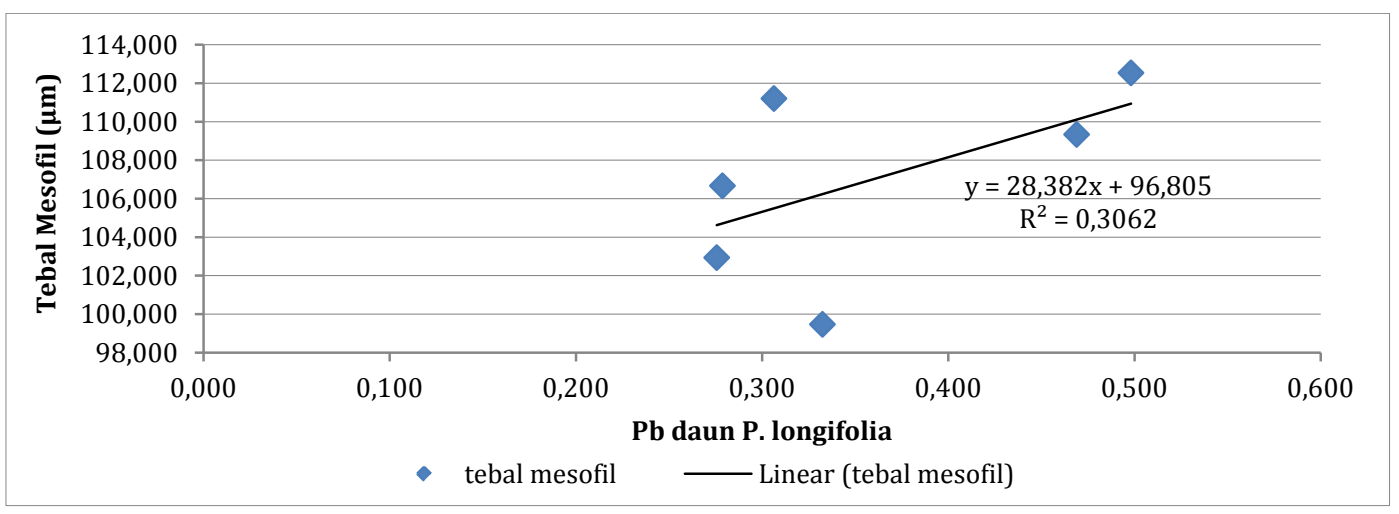

Grafik 3. Korelasi Pb daun P. longifolia dengan tebal jaringan mesofil

Hasil ANOVA menunjukkan bahwa konsentrasi $\mathrm{Pb}$ daun berpengaruh sangat nyata terhadap panjang stomata. Hasil uji korelasi antara $\mathrm{Pb}$ dalam daun $P$. longifolia dengan panjang stomata didapatkan nilai $r<$ 0,05 sehingga dapat disimpulkan bahwa tidak ada hubungan antara konsentrasi $\mathrm{Pb}$ daun $P$. longifolia terhadap panjang stomata. Lebar stomata daun P.longifolia diperoleh informasi bahwa lebar stomata pada daun $P$. longifolia tertinggi terdapat di Jalan Komisaris Bambang Suprapto yaitu 20,53 $\pm 2,43 \mu \mathrm{m}$ dan lebar stomata terendah terdapat di jalan DR.

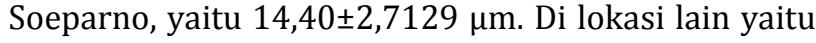


di jalan dr. Angka - dr. Suharso, HR. Bunyamin, Jenderal Soedirman, dan, Gerilya panjang stomata daun $P$. longifolia berturut-turut mengalami kenaikan yaitu masing-masing $14,67 \pm 2,53 \mu \mathrm{m} ; 18,13 \pm 1,26 \mu \mathrm{m}$; $19,73 \pm 4,45 \mu \mathrm{m}$; dan 20,00 $\pm 3,98 \mu \mathrm{m}$. Hasil ANOVA menunjukkan bahwa konsentrasi $\mathrm{Pb}$ daun berpengaruh sangat nyata terhadap lebar stomata. Hasil uji korelasi antara $\mathrm{Pb}$ dalam daun dengan lebar stomata didapatkan nilai $r<0,05$ sehingga dapat disimpulkan bahwa tidak ada hubungan antara konsentrasi $\mathrm{Pb}$ daun $P$. longifolia terhadap lebar stomata.

Berdasarkan hasil pengukuran tebal jaringan mesofil $P$. longifolia diperoleh hasil tertinggi terdapat

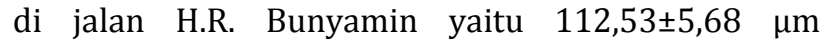
sedangkan di lokasi lain yaitu di Jalan Kom. Bambang Suprapto, Jalan dr. Angka - dr. Suharso, Jalan DR. Soeparno, Jalan Jenderal Soedirman, dan Jalan Gerilya berturut-turut mengalami penurunan yaitu masingmasing sebesar $111,20 \pm 6,57 \mu \mathrm{m} ; 109,33 \pm 7,21 \mu \mathrm{m}$; $106,67 \pm 4,66 \mu \mathrm{m} ; 102,93 \pm 2,80 \mu \mathrm{m}$; dan 99,467 $\pm 7,879$ $\mu \mathrm{m}$. Hasil ANOVA menunjukkan bahwa konsentrasi $\mathrm{Pb}$ daun berpengaruh sangat nyata terhadap tebal jaringan mesofil. Hasil uji korelasi antara $\mathrm{Pb}$ dalam daun dengan tebal jaringan mesofil didapatkan nilai $r$ $>0,05$ sehingga dapat disimpulkan bahwa ada hubungan antara konsentrasi $\mathrm{Pb}$ daun $P$. longifolia terhadap tebal jaringan mesofil dengan persamaan regresi linear yang didapat yaitu $Y=28,38 X+96,80$ (Grafik 3). Berdasarkan hasil analisis regresi linear antara $\mathrm{Pb}$ daun $P$. longifolia dengan tebal mesofil didapatkan nilai $t>0,01$ sehingga dapat disimpulkan bahwa ada hubungan sangat nyata antara konsentrasi $\mathrm{Pb}$ yang terakumulasi dalam daun dengan tebal mesofil, semakin meningkat konsentrasi $\mathrm{Pb}$ yang terakumulasi dalam daun maka tebal mesofil semakin meningkat. Derajat keeratan hubungan $\left(r^{2}\right)$ antara $\mathrm{Pb}$ daun $P$. longifolia dengan tebal mesofil sebesar $12 \%$.

\section{KESIMPULAN DAN SARAN}

Berdasarkan hasil dan pembahasan, kesimpulan yang diperoleh sebagai berikut:

1. Konsentrasi Pb udara ambien di enam jalan utama di purwokerto berkisar antara 0,0048 $0,1020 \mu \mathrm{g} / \mathrm{m}^{3}$, sehingga dikatagorikan masih berada di bawah ambang batas baku mutu udara ambien di Propinsi Jawa Tengah, yaitu $2 \mu \mathrm{g} / \mathrm{m}^{3}$.

2. Kemampuan tanaman $P$. longifolia dalam mengakumulasi $\mathrm{Pb}$ udara ambien cenderung mengalami peningkatan seiring dengan meningkatnya konsentrasi $\mathrm{Pb}$ udara ambien.

3. Respon anatomis tanaman peneduh jalan $P$. longifolia dalam mengakumulasi $\mathrm{Pb}$ udara ambien menunjukkan adanya perubahan seiring meningkatnya akumulasi $\mathrm{Pb}$ dalam daun.

4. Konsentrasi $\mathrm{Pb}$ daun $P$. Longifolia mampu menurunkan jumlah stomata dan meningkatkan tebal jaringan mesofil, tetapi tidak berhubungan dengan panjang dan lebar stomata.

Berdasarkan hasil penelitian tersebut, perlu dilakukan penelitian lebih lanjut mengenai respon fisiologis dan enzimatis $P$. longifolia dalam mengakumulasi $\mathrm{Pb}$ udara.

\section{DAFT AR REFERENSI}

Aeny N. 2008. Uji absorbsi logam Pb menggunakan biomassa Sargassum cinereum J. G. Agardh yang terpapar leachate TPA Gunung Tugel [skripsi]. Purwokerto: Fakultas Biologi Universitas Jenderal Soedirman.

Antari AARJ, Sundra IK. 2007. Kandungan timah hitam (Plumbum) pada tanaman peneduh jalan di kota Denpasar. J. Bumi Lestari 7 (1): 31-38.

Fergusson JE. 1990. The heavy element chemistry, environmental impact and health effect.

Haryanti S. 2010. Jumlah dan distribusi stomata pada daun beberapa spesies tanaman dikotil dan monokotil. Bul. Anatomi dan Fisiologi 2(18): 21-28.

Hendrasarie N. 2007. Kajian efektifitas tanaman dalam menjerap kandungan Pb di udara. J. Rekayasa Perencanaan 2(3).

Hughes MK, Lepp NW, Phipps DA. 1980. Aerial heavy metal pollution and terrestrial ecosystems. Advances in Ecological Research (11): 217-327.

Juwarno, Samiyarsih S. 2010. Respon fisiologi dan anatomis tanaman ubi jalar (Ipomoea batatas L.) akibat pemberian pupuk cair bionutrient. Laporan Hasil Penelitian. Purwokerto: Fakultas Biologi Universitas Jenderal Soedirman.

Johansen DA. 1940. Plant microtechnique. 1st. New York: McGrawHill Publication in the Botanical Sciences.

Ruhaibah. 2011. Akumulasi logam $\mathrm{Pb}, \mathrm{Cu}$, Dan $\mathrm{Zn}$ pada tanaman pelindung di jalur hijau kota Banda Aceh [tesis]. Bogor: Sekolah Pascasarjana Institut Pertanian Bogor.

Santoso SN. 2011. Penggunaan tumbuhan sebagai pereduksi pencemaran udara [skripsi]. Jurusan Teknik Lingkungan: Fakultas Teknik Sipil Dan Perencanaan Institut Teknologi Sepuluh Nopember.

SK.Gubernur Jawa Tengah Nomor 8 Tahun 2001. Baku Mutu Udara Ambien di Propinsi Jawa Tengah.

Treshow M, Anderson FK. 1989. Plant stress from air pollution. New York: John Willey and Sons Ltd. Chichester.

Wardhana W. 2001. Dampak pencemaran lingkungan. Yogyakarta: Andi Offset.

Widagdo S. 2005. Tanaman elemen lanskap sebagai biofilter untuk mereduksi polusi timbal $(\mathrm{Pb})$ di udara [disertasi]. Bogor: Sekolah Pasca Sarjana Institut Pertanian Bogor.

Widowati W, Sastiono A, Jusuf R . 2008. Efek toksik logam. Yogyakarta: Andi. 